\title{
EFEKTIVITAS ASI EKSKLUSIF PADA PERKEMBANGAN MOTORIK KASAR BAYI
}

\author{
Melati Julizar ${ }^{1}$, Muslim² $^{2}$ \\ 1,2STIKes Getsempena Lhoksukon \\ 1email: yulizarmelaty@gmail.com \\ email: mmuslem666@gmail.com
}

\section{ABSTRACT THE EFFECTIVENESS OF EXCLUSIVE BREASTFEEDING ON INFANT GROSS MOTOR DEVELOPMENT}

Background: The coverage of exclusive breastfeeding in Indonesia has not reached the expected rate, which is around $80 \%$. Exclusive breastfeeding is very important for the baby's growth and development. Babies who are exclusively breastfed and with good nutritional status have normal gross motor development. Breastfeeding exclusively supports the baby's growth, improves brain cell development, language development, and motor development of the baby because breast milk contains various nutrients that can promote growth and brain development. This study aims to analyze the effectiveness of exclusive breastfeeding on infant gross motor development in Syamtalira Aron, Aceh Utara.

Methods: This study used a comparative design with a cross sectional approach. The number of research respondents was 92 respondents, with a total sampling technique. Exclusive breastfeeding data and gross motor development were collected using a Developmental Pre-Screening Questionnaire (KPSP).

Results: In this study, it is known that the frequency distribution of exclusive breastfeeding was 37 people (37.5\%), and 55 people (62.5\%) were not exclusively breastfed. The data analysis used the Mann Whitney U. The results of the bivariable study showed that the exclusive breastfeeding group had a minimum value of 7 and a maximum value of 10. While the non-ASI group had a median score of 7 with a minimum value of 6 and a maximum of 10 , the average rating of the exclusive breastfeeding group was 66.50 higher than the non-ASI group with a value of 33.05 and a $p$-value of 0,000 .

Conclusion: Exclusive breastfeeding is better than non-exclusive breastfeeding for infants aged 0-6 months for infant development.

Suggestion: it is hoped that further researchers can research using a qualitative approach so that they can find out more deeply and get accurate information about exclusive breastfeeding and it is hoped that mothers who have babies can exclusively breastfeed for six months.

Key words: Exclusive breastfeeding; Gross motor development of infants

\section{ABSTRAK}

Latar Belakang: Cakupan ASI eksklusif di Indonesia belum mencapai angka yang diharapkan, yaitu sekitar $80 \%$. ASI eksklusif sangat penting untuk tumbuh kembang bayi. Bayi yang mendapat ASI eksklusif dan berstatus gizi baik mempunyai perkembangan motorik kasar normal. Pemberian ASI secara eksklusif mendukung pertumbuhan bayi, meningkatkan perkembangan sel otak, perkembangan bahasa, dan perkembangan motorik bayi karena ASI mengandung berbagai nutrien yang dapat meningkatkan pertumbuhan dan perkembangan otak. Penelitian ini bertujuan untuk menganalisis efektifitas Asi Eksklusif pada perkembangan motorik kasar bayi di Syamtalira Aron, Aceh Utara.

Metode: Penelitian ini menggunakan design komparatif dengan pendekatan cross sectional. Jumlah responden penelitian yaitu 92 responden, dengan teknik pengambilan sampel total sampling. Data ASI Eksklusif dan perkembangan motorik kasar diambil dengan menggunakan kuesioner Pra Skrining Perkembangan (KPSP).

Hasil: Pada penelitian ini diketahui distribusi frekuensi pemberian ASI Eksklusif sebanyak 37 orang (37,5\%), dan tidak ASI eksklusif sebanyak 55 orang (62,5\%). Analisis data menggunakan Mann Whitney U. Hasil penelitian bivariabel menunjukkan median kelompok ASI Eksklusif 9 dengan nilai minimal 7 dan nilai maksimal 10. Sedangkan kelompok Tidak ASI nilai median 7 dengan nilai minimal 6 dan maksimal 10, rata-rata peringkat kelompok ASI Eksklusif 66,50 lebih tinggi dibandingkan dengan kelompok Tidak ASI dengan nilai 33,05 serta nilai pvalue 0,000 . 
Kesimpulan: Pemberian ASI Eksklusif lebih baik dari pada yang tidak diberi ASI eksklusif pada bayi usia 06 bulan untuk perkembangan bayi.

Saran : diharapkan bagi peneliti selanjutnya dapat meneliti dengan menggunakan pendekatan kualitatif sehingga dapat menggali lebih dalam dan didapatkan informasi yang lebih akurat mengenai Asi Eksklusif dan diharapkan bagi ibu yang memiliki bayi agar dapat memberikan ASI secara eksklusif selama enam bulan.

Kata kunci: ASI Eksklusif; Perkembangan motorik kasar bayi

\section{PENDAHULUAN}

Data Badan Kesehatan Dunia (WHO) tahun 2016 masih menunjukkan rata-rata angka pemberian ASI eksklusif di dunia baru berkisar 38 persen. Di Indonesia meskipun sejumlah besar perempuan (96\%) menyusui anak mereka dalam kehidupan mereka, hanya $42 \%$ dari bayi yang berusia di bawah 6 bulan yang mendapatkan ASI eksklusif. Pada saat anak-anak mendekati ulang tahunnya yang ke dua, hanya $55 \%$ yang masih diberi ASI. International Baby Food Action Network (IBFAN) (2014), Indonesia menduduki peringkat ke tiga terbawah dari 51 negara di dunia yang mengikuti penilaian status kebijakan dan program pemberian makan bayi dan anak (Saputra, 2016).

Berdasarkan hasil Riset Kesehatan Dasar (Riskesdas) 2018, di Indonesia pemberian ASI baru mencapai 37,3\%, ASI Parsial 9,3 dan ASI Predominan $3,3 \%$. Makanan yang banyak diberikan merupakan makanan prelakteal yang merupakan makanan atau minuman yang diberikan kepada bayi sebelum diberikan ASI, presentase yang tertinggi dari makanan prelakteal adalah susu formula, yaitu sebanyak 79,8\% (Riskesdas, 2018).

Bertitik tolak dari rangkaian diatas cakupan ASI eksklusif di Indonesia belum mencapai angka yang diharapkan, yaitu sekitar $80 \%$. Pada tahun 2017, secara nasional cakupan ASI Eksklusif sebesar $61,3 \%$ sedikit mengalami peningkatan dari tahun 2016 yaitu $54 \%$ demikian juga jika dibandingkan dengan tahun 2013 cakupan ASI eksklusif telah mencapai $54,3 \%$. Bila diteleah, provinsi yang paling tinggi pemberian ASI eksklusif adalah Nusa Tenggara Barat $87,35 \%$ dan yang terendah adalah provinsi Papua $15,32 \%$. Jenis makan yang paling banyak diberikan kepada bayi baru lahir adalah susu formula, yaitu sebesar 79,8 (Riskesdas, 2018); (Kemenkes RI, 2017).

Anak yang mendapatkan ASI sejak dini umumnya mengalami perkembangan dengan cepat dibandingkan dengan anak yang hanya mendapatkan susu formula karena pada anak yang hanya mendapatkan susu formula biasanya mengalami perkembangan yang kurang atau terlambat dan akan mempengaruhi kualitas anak (Khamzah, 2012).
ASI eksklusif sangat penting untuk tumbuh kembang bayi, maka kementrian kesehatan telah menerbitkan surat keputusan menteri kesehatan nomor 450/MENKES/SK/VI/2004 tentang pemberian ASI secara eksklusif di Indonesia menetapkan ASI eksklusif di Indonesia selama 6 bulan dan dianjurkan dilanjutkan sampai dengan anak berusia 2 tahun atau lebih dengan pemberian makanan tambahan yang sesuai dan tenaga kesehatan agar menginformasikan kepada semua ibu yang baru melahirkan untuk memberikan ASI eksklusif dengan mengacu pada 10 langkah keberhasilan menyusui (Infodatin, 2015).

Dari hasil penelitian Riadini (2015), terdapat pengaruh yang positif dan signifikan secara statistik antara ASI eksklusif dan status gizi dengan perkembangan motorik kasar bayi usia 6-24 bulan. Bayi yang mendapat ASI eksklusif dan berstatus gizi baik mempunyai perkembangan motorik kasar normal. Pemberian ASI secara eksklusif mendukung pertumbuhan bayi, meningkatkan perkembangan sel otak, perkembangan bahasa, dan perkembangan motorik bayi karena ASI mengandung berbagai nutrien diantaranya taurin, laktosa dan asam lemak ikatan panjang seperti DHA, AA, omega 3 dan omega 6 yang dapat meningkatkan pertumbuhan dan perkembangan otak, sehingga pemberian ASI secara eksklusif dapat mempengaruhi perkembangan bayi secara keseluruhan termasuk perkembangan motorik kasar bayi Riadini, 2015). Hal ini sejalan dengan penelitian yang dilakukan oleh Adhim (2020) bahwa terdapat hubungan signifikan antara ASI Eksklusif dengan perkembangan motorik kasar anak usia 6 24 bulan.

Berdasarkan laporan Dinas Kesehatan Provinsi (2017), cakupan ASI eksklusif di Aceh sebanyak 55\%. Cakupan ASI eksklusif ini masih berada di bawah angka nasional. Menurut data profil kesehatan Aceh, cakupan pemberian ASI eksklusif pada bayi 0-6 bulan di Aceh tahun 2015 sebanyak 53\% menurun pada tahun 2016 menjadi 50\% dan pada tahun 2017 sedikit meningkat menjadi 55\% (Dinkes Aceh, 2017). 
Tujuan penelitian ini adalah menganalisis efektifitas Asi Eksklusif pada perkembangan motorik kasar bayi di Syamtalira Aron, Aceh Utara

\section{METODOLOGI PENELITIAN}

Jenis penelitian ini adalah penelitian analitik menggunakan design komparatif dengan pendekatan cross sectional, karena bertujuan untuk mengetahui perbandingan efektifitas Asi Eksklusif pada perkembangan motorik kasar bayi di wilayah Kecamatan Syamtalira Aron, Aceh Utara, serta variabel independen dan dependen diteliti pada saat bersamaan (Notoadmodjo, 2010).

Sumber data pada penelitian ini, yaitu data primer dan data sekunder. Data primer pada penelitian ini adalah dengan kuesioner yang ditanyakan kepada ibu bayi. Data sekunder pada penelitian ini diperoleh dari tempat penelitian.

Penelitian dilaksanakan di Syamtalira Aron, Aceh Utara. Populasi penelitian seluruh ibu-ibu yang mempunyai bayi 7-12 bulan yang berada di Syamtalira Aron, Aceh Utara, sampel berjumlah 92 orang (total sampling). Instrumen yang digunakan dalam penelitian ini adalah kuesioner yang ditanyakan kepada ibu. Cara pengumpulan data menggunakan ceklist KPSP. Teknik analisis data, yaitu analisis univariat dan bivariat.

\section{HASIL PENELITIAN}

Analisa Univariat

Tabel 1.

Distribusi frekuensi Asi Eksklusif

\begin{tabular}{|c|c|c|}
\hline Asi eksklusif & $\mathbf{F}$ & $\%$ \\
\hline $\mathrm{Ya}$ & 37 & 40 \\
\hline Tidak & 55 & 60 \\
\hline Total & 92 & 100 \\
\hline
\end{tabular}

Berdasarkan tabel di atas menunjukkan bahwa dari 92 orang responden sebagian besar bayi tidak diberi asi eksklusif sebanyak 55 (60\%).

Tabel 2.

Distribusi frekuensi perkembangan motorik kasar pada bayi usia 7-12 bulan

\begin{tabular}{lcc}
\hline Perkembangan Motorik kasar & F & $\%$ \\
\hline Sesuai & 37 & 40,2 \\
Meragukan & 48 & 52,2 \\
Penyimpangan & 7 & 7,6 \\
\hline \multicolumn{1}{c}{ Total } & 92 & 100 \\
\hline
\end{tabular}

Berdasarkan tabel 2. di atas menunjukkan bahwa dari 92 orang responden yang diteliti, di simpulkan bahwa perkembangan motorik kasar meragukan sebanyak $48(52,2 \%)$.

\section{Analisis Bivariat}

Berdasarkan tabel 3. dibawah menunjukan bahwa Perbedaan Asi Eksklusif dan Tidak Asi Eksklusif pada penelitian ini diidentifikasi dengan membandingkan selisih nilai perkembangan motorik kasar bayi kelompok ASI Eksklusif dengan perkembangan motorik kasar bayi kelompok tidak ASI Eksklusif diuji menggunakan uji Mann Whitney U. Berdasarkan uji tersebut ditemukan median kelompok ASI Eksklusif 9 dengan nilai minimal 7 dan nilai maksimal 10. Sedangkan kelompok Tidak Asi Eksklusif nilai median 7 dengan nilai minimal 6 dan maksimal 10, rata-rata peringkat kelompok ASI Eksklusif 66,50 lebih tinggi dibandingkan dengan kelompok Tidak Asi Eksklusif dengan nilai 33,05 serta nilai $p$ value 0,000 . Dari hasil penelitian ini dapat disimpulkan bahwa pemberian ASI Eksklusif lebih baik dari pada tidak Asi Eksklusif pada bayi usia 0-6 bulan untuk perkembangan motorik kasar bayi.

Tabel 3

Efektifitas Asi Eksklusif Pada Perkembangan Motorik Kasar Bayi Di Syamtalira Aron, Aceh Utara

\begin{tabular}{lccccc}
\hline \multicolumn{1}{c}{ Variabel } & $\mathbf{n}$ & Mean Rank & Median & Min-Maks & P value \\
\hline ASI Eksklusif & 37 & 66,50 & 9 & $(7-10)$ & 0,000 \\
Tidak ASI Eksklusif & 55 & 33,05 & 7 & $(6-10)$ & \\
\hline
\end{tabular}

\section{PEMBAHASAN}

Temuan penelitian didapatkan hasil bahwa pemberian ASI Eksklusif lebih baik dari pada tidak Asi Eksklusif pada bayi usia 0-6 bulan untuk perkembangan motorik kasar bayi. dengan nilai $p$ value $=0,000<0,05$.

Hal ini sejalan dengan penelitian yang dilakukan Erisna, Hasil penelitian, menyebutkan bahwa sebagian besar Batita tidak mendapatkan ASI Eksklusif dengan presentase 53,7\%, sebagian besar Batita mengalami perkembangan motorik sesuai dengan presentase $58,5 \%$ dan Sebanyak $72,7 \%$ Batita tidak mendapatkan ASI eksklusif memiliki perkembangan motorik yang meragukan. Hasil analisa data menunjukkan bahwa ada hubungan pemberian ASI eksklusif dengan 
perkembangan motorik batita $(p=0,000)$ (Erisna, 2018).

Fina Riyanti, dkk (2013) menunjukkan jumlah bayi yang diberi ASI eksklusif sebanyak $68,4 \%$ dan diberi ASI dan PASI ada 12 bayi 31,6\%. Hasil deteksi dini perkembangan sesuai ada $57,9 \%$, meragukan $34,2 \%$, dan penyimpangan $7,9 \%$. Ada hubungan antara pemberian ASI eksklusif dengan perkembangan bayi usia $6-12$ bulan. Dapat dilihat dari hasil uji chi - square, yaitu nilai $\times 2$ hitung 12,259 dan x2 tabel 5,991 dengan taraf signifikansi 0,05 . $x 2$ hitung $>\times 2$ tabel $(12,259>5,991)$ atau $p$ $<0,05(0,002<0,05)$. Hal ini sejalan dengan penelitian Nurjannah (2015) menyatakan ASI eksklusif mempengaruhi perkembangan anak usia 6-12 bulan.

Hasil penelitian ini sesuai dengan hasil penelitian oleh Ali, et al (2014), anak-anak yang mendapatkan ASI eksklusif selama 6 bulan atau lebih memiliki skor ASQ (Ages and Stages Questionnaire) lebih tinggi dengan perolehan nilai $p$ $(0,004)$ pada sektor motorik kasar dibandingkan dengan anak-anak yang tidak mendapatkan ASI eksklusif dengan nilai $p(0,091)$, sehingga dapat disimpulkan bahwa pemberian ASI eksklusif berperan penting dalam tumbuh kembang anak, khususnya pada sektor motorik kasar (Ali, 2014).

Dari hasil penelitian Yoda Fauziyah (2015) juga didapatkan berdasarkan uji statistik dengan uji Chi-square menunjukkan nilai $p=0,043$ sehingga ada hubungan yang bermakna antara pemberian ASI dengan perkembangan motorik kasar pada bayi. Penelitian ini sejalan dengan penelitian sebelumnya yang dilakukan oleh Arifah (2013) menyatakan bahwa ada hubungan positif antara pemberian ASI eksklusif dengan perkembangan motorik kasar anak usia 6-12 bulan (Fauziyah, 2015); (Arifah, 2013).

Berdasarkan penelitian Nurlaila (2017) dengan judul Hubungan Pemberian Asi Eksklusif Dengan Perkembangan Motorik Pada Bayi diketahui bahwa Hasil penelitian menggunakan uji non parametrik chi- square menunjukkan hasil nilai $p=0,000$, karena nilai $p<0,05$ maka dapat disimpulkan bahwa ada hubungan yang bermakna antara pemberian ASI eksklusif dengan perkembangan motorik kasar pada bayi usia 6-18 bulan. Selaras dengan penelitian yang dilakukan oleh Azhari (2019), menunjukkan hasil bahwa ada hubungan antara pemberian ASI eksklusif dan non eksklusif dengan perkembangan motorik kasar pada bayi usia 6-12.

Menurut Muslihatun (2011), Perkembangan pada seorang anak dipengaruhi oleh beberapa hal, antara lain kematangan dan latihan (belajar), yaitu olahraga atau latihan fisik (stimulasi) yang dilakukan oleh ibu dan keluarga. Siti Nur Kholifah, dkk (2014) mengungkapkan hasil penelitiannya tentang perkembangan motorik kasar melalui stimulasi ibu. Dari hasil penelitian ini dapat disimpulkan bahwa tindakan stimulasi ibu terhadap perkembangan motorik kasar bayi dalam kategori baik, karena semakin baik tindakan stimulasi yang diberikan oleh ibu maka akan berpengaruh pada perkembangan motorik kasar bayi yang normal dan sesuai (Muslihatun, 2011); (Kholifah, 2014).

Bertitik tolak dari rangkaian diatas maka dapat disimpulkan dari hasil penelitian ini bahwa ASI sangat berpengaruh terhadap pertumbuhan dan perkembangan bayi. Pada tahap perkembangan, yaitu motorik kasar merupakan hal yang sangat penting untuk diteleah kembali sehingga dalam proses meningkatkan perkembangan bayi diperlukan nutrisi yang sesuai untuk bayi. Dari hasil penelitian tersebut ASI merupakan nutrisi yang paling cocok dan tepat untuk meningkatkan perkembangan motorik kasar bayi. Tidak hanya nutrisi bahkan stimulasi juga berperan penting dalam perkembangan motorik kasar bayi.

\section{KESIMPULAN}

Hasil penelitian yang dilakukan mengenai efektifitas Asi Eksklusif pada perkembangan motorik kasar bayi di Syamtalira Aron, Aceh Utara, dapat disimpulkan bahwa sebagian besar bayi tidak diberikan ASI secara eksklusif yang berjumlah 55 bayi $(60 \%)$ dan Rata-rata peringkat kelompok ASI Eksklusif 66,50 lebih tinggi dibandingkan dengan kelompok Tidak ASI Eksklusif dengan nilai 33,05 serta nilai $p$ value 0,000 . Dari hasil penelitian ini dapat disimpulkan bahwa pemberian ASI Eksklusif lebih baik dari pada tidak Asi Eksklusif pada bayi usia 0-6 bulan untuk perkembangan motorik kasar bayi.

\section{SARAN}

Bagi penelitian selanjutnya penelitian selanjutnya bisa meneliti dengan menggunakan pendekatan kualitatif sehingga dapat menggali lebih dalam dan didapatkan informasi yang lebih akurat mengenai Asi Eksklusif ,bagi ibu yang memiliki bayi agar dapat memberikan ASI secara eksklusif selama enam bulan.

\section{DAFTAR PUSTAKA}

Adhim, M. (2020). Hubungan Pemberian Asi Eksklusif Dengan Perkembangan Motorik Kasar Anak Usia 6-24 Bulan Di Wilayah Kerja Puskesmas Turen (Doctoral 
dissertation, Universitas Muhammadiyah Malang).

Ali, Syed Sadat, et al. (2014). The Impact of Nutrition on Child Development at 3 Years in a Rural Community of India. International Journal of Preventive Medicine, 5 (4).

Azhari, A., \& Wahyuni, S. (2019). Hubungan Antara Pemberian ASI Eksklusif dan Non Eksklusif dengan Perkembangan Motorik Kasar Bayi Usia 6-12 Bulan di Posyandu Wilayah Kerja Puskesmas Makam Haji (Doctoral dissertation, Universitas Muhammadiyah Surakarta).

Arifah, D. A. (2013). Hubungan Pemberian ASI Eksklusif dengan Perkembangan Motorik Kasar Anak Usia 6-12 Bulan di Kelurahan Sangkrah Surakarta.

Dinas Kesehatan Provinsi Aceh. (2017). Profil kesehatan Aceh: Dinkes Aceh.

Erisna, A., Jasmi, J., \& Alyensi, F. (2018). Hubungan Pemberian Asi Eksklusif Dengan Perkembangan Motorik Batita Di Kelurahan Limbungan Baru Wilayah Kerja Puskesmas Rawat Inap Karya Wanita Kota Pekanbaru Tahun 2017. Jurnal Ibu Dan Anak, 6(1), 1016.

Fauziyah, Y. (2015). Hubungan antara Status Pemberian ASI dengan Perkembangan Motorik Kasar pada Bayi Usia 7-12 Bulan di Desa Tohudan Kecamatan Colomadu Kabupaten Karanganyar. [Skripsi IImiah]. Surakarta: Fakultas IImu Kesehatan UMS.

IBI. (2018). Pekan ASI Se-Dunia (World Breastfeeding Week). Diunduh dari: https://www.ibi.or.id/id/article_view/A201808 08002/pekan-asi-se-dunia-worldbreastfeeding-week.html\#:

INFODATIN. (2015). Situasi dan Analisa Asi Eksklusif. Diunduh dari: http://www.depkes.go.id/resources/download /pusdatin/infodatin/infodatin-asi.pdf.Tanggal 21 Januari 2020.

Kementrian Kesehatan RI. (2017). Profil Kesehatan Indonesia. Jakarta: Kementrian Kesehatan RI 2018.
Khamzah, S. (2012). Segudang Keajaiban ASI. Jogjakarta: Flashbooks.

Kholifah, S. N., Fadillah, N., As'ari, H., \& Hidayat, T. (2014). Perkembangan motorik kasar bayi melalui stimulasi ibu di kelurahan kemayoran Surabaya. Jurnal Sumber Daya Manusia Kesehatan, 1(1).

Muslihatun, Nur W. (2011). Asuhan Neonatus, Bayi dan Balita. Yogyakarta: Fitramaya.

Notoadmodjo, S. (2010). Metodologi Penelitian Kesehatan, Jakarta: Rineka Cipta.

Nurjanah, S. (2015). ASI Eksklusif Meningkatkan Perkembangan Bayi Usia 6-12 Bulan di Wilayah Kerja Puskesmas Banyu Urip Surabaya. Journal of Health Sciences, 8(2).

Nurlaila, N., Riyatun, K., \& Iswati, N. (2017). Hubungan Pemberian ASI Eksklusif dengan Perkembangan Motorik Pada Bayi. Jurnal IImiah Kesehatan Keperawatan, 13(2).

Riyanti, F., \& Hanifah, L. (2014). Hubungan pemberian asi eksklusif dengan perkembangan bayi usia 6-12 bulan di desa carikan juwiring klaten tahun 2013. Jurnal Kebidanan Indonesia: Journal of Indonesia Midwifery, 5(2).

Riset Kesehatan Dasar (Riskesdas). (2018). Hasil Utama Riskesdas 2018. Kementrian Kesehatan Badan Penelitian dan Pengembangan Kesehatan. Diunduh dari: http://stikepppnijabar.ac.id/images/RISKESDAS_LAUNC HING_301018_edit271018_nowo_EditKaban_01.pdf Tanggal 17 Januari 2020.

Saputra, Y. (2016). Pekan ASI Sedunia. Diunduh dari:

http://www.rappler.com/indonesia/142238pekan-asi-sedunia-indonesia-masih-rendah Tanggal 15 Januari 2020.

Utami, R. W. Faktor-Faktor Yang Mempengaruhi Perkembangan Motorik Kasar Bayi Usia 6-24 Bulan Di Klinik Baby Smile. 